\title{
PENINGKATAN KINERJA ADMINISTRASI PENJUALAN CHEMICAL WATER TREATMENT PRODUCT DENGAN PEMANFAATAN SISTEM INFORMASI
}

\author{
Maimunah $^{1}$, Berkat Jaya Batee ${ }^{2}$, Mega Agustina Margareta ${ }^{3}$ \\ Dosen STMIK Raharja Tangerang ${ }^{1,2}$, Mahasiswa Jurusan Teknik Informatika STMIK Raharja ${ }^{3}$ \\ J1. Jenderal Sudirman No. 40 Modern, Cikokol, Tangerang ${ }^{1,2,3}$ \\ email:maimunah@raharja.info ${ }^{1}$,berkat@raharja.info ${ }^{2}$,mega.agustina@raharja.info ${ }^{3}$
}

\begin{abstract}
Abstrak
Penggunaan komputer dan sistem-sistemnya sudah menjadi kebutuhan yang utama dalam rangka meningkatkan kinerja suatu perusahaan. Perusahaan pengolahan air limbah adalah perusahaan yang bergerak dalam bidang penjualan barang chemical water treatment product. Dimana dalam pengolahan datanya dilakukan secara manual akibatnya sering terjadi masalah seperti penomoran yang sama dengan invoice lain yang mengakibatkan kekeliruan dalam pembuatan laporan penjualan barang, belum terpenuhinya atas pengendalian sistem administrasi dan laporan penjualan. Dalam penelitian ini menggunakan MySQL untuk pengelolaan databasenya yang dimana dapat menyimpan seluruh laporan penjualan dan menyajikan data yang akurat, serta menghasilkan laporan tepat waktu sesuai dengan kebutuhan yang diinginkan. Semua data yang berhubungan dengan sistem laporan penjualan akan tersimpan dengan baik dan hasilnya lebih akurat. PHP merupakan bahasa pemrograman yang digunakan untuk rancangan program yang usulan dan Dreamweaver sebagai tools pembuatan program.
\end{abstract}

Kata kunci : Penjualan, Sistem Informasi, administrasi penjualan

\begin{abstract}
The use of computers and systems has become a major requirement in order to improve the performance of a company. Wastewater treatment company is a company engaged in the sale of chemical water treatment product. Where in the data processing is done manually consequently often occur problems such as the same numbering with other invoices that result in errors in the manufacture of sales reports of goods, has not fulfilled the administrative control system and sales reports. In this study using MySQL for database management which can store all sales reports and present accurate data, and generate timely reports in accordance with the desired needs. All data related to the sales report system will be well stored and the results are more accurate. PHP is a programming language used for the design of proposed programs and Dreamweaver as a tool making program.
\end{abstract}

Keywords: Sales, Information System, sales administration

\section{PENDAHULUAN}

Kemajuan sistem informasi dalam perkembangan dan laju perusahaan sangat mempengaruhi minat suatu perusahaan untuk memanfaatkan sistem informasi tersebut. Para pelaku dunia usaha 
memanfaatkan sistem informasi berbasis web dalam melengkapi kebutuhan dan keperluannya. Pemanfaatan tersebut akan mempermudah suatu pekerjaan seperti keputusan yang akan diambil lebih tepat, pengolahan data yang lebih cepat, menghemat waktu dan biaya. Selain itu, sistem informasi yang berbasis web juga dapat meningkatkan kinerja suatu perusahaan dan sumber informasi yang dapat diakses oleh pengguna internet. Perusahaan yang bergerak dalam bidang pengolahan air limbah atau chemical water treatment product yaitu perusahaan yang menjual berbagai jenis bahan kimia dan jasa pengolahan air limbah serta berbagai sparepart mesin mesin pabrik seperti Boiler, Chiller, Condensor, dan lain lain.

Maka hasil informasi tentang laporan administrasi penjualan sangat diperlukan dalam memenuhi laporan yang tepat, cepat dan akurat. Pada Perusahaan ini penerapan sistem yang berjalan pada saat ini masih secara semi komputerisasi, yaitu sebatas pembuatan laporan manual dan penyimpanan data dengan menggunakan Microsoft Excel dan Microsoft Word. Pengelolahan data seperti pencatatan pada buku laporanpun juga masih dilakukan secara manual. Peran sistem informasi administrasi penjualan sangat berdampak dalam kelangsungan hidup suatu perusahaan karena dari hasil laporan administrasi penjualan yang dilakukan untuk mengetahui tentang pendapatan bagi perusahaan apakah pendapatan naik ataukah turun. Dengan demikian perlu diadakan penelitian, analisis sistem dan perancangan sistem informasi administrasi penjualan sehingga system informasi yang dihasilkan dapat benar-benar sesuai dengan harapan pimpinan perusahaan untuk mengetahui tentang pendapatan dan mendukung pengambilan keputusan untuk menentukan langkah apa yang harus dilakukan untuk menciptakan sistem administrasi penjualan dimasa yang akan datang.

\section{Permasalahan}

Dalam sistem administrasi penjualan chemical water treatment product yang berjalan saat ini belum berjalan dengan baik terkadang masih ada penulisan invoice ganda ataupun penomoran yang sama dengan invoice lain yang mengakibatkan kekeliruan dalam pengecekan pembayaran pelanggan. Sistem administrasi penjualan chemical water treatment product yang berjalan saat ini belum menghasilkan hasil yang maksimal dalam pembuatan laporan penjualan ataupun administrasi penjualan.

\section{LANDASAN TEORI}

\subsection{Definisi web}

Web dapat diartikan sebagai kumpulan halaman yang menampilkan informasi data teks, data gambar diam atau gerak, data animasi, suara, video, dan atau gabungan dari semuanya baik yang bersifat statis maupun dinamis yang membentuk suatu rangkaian bangunan yang saling terkait dimana masing-masing dihubungkan dengan jaringan halaman (Hyperlink)[1].

\subsection{Definisi Aplikasi}

Aplikasi merupakan program yang dikembangkan untuk memenuhi kebutuhan pengguna dalam menjalankan pekerjaan tertentu.[2]

\subsection{Definisi administrasi}

Administrasi adalah sebuah bangunan hubungan yang tertata secara sistematis yang membentuk sebuahjaringan yang saling bekerjasama satu sama lainnya untuk mendukung terwujudnya suatu mekanisme kerja yang tersusun dan mencapai tujuan yang dharapkan.[3] 


\subsection{Definisi Water Treatment Chemical}

Waste water treatment is important area of investigation in environmental science and engineering. The polluted water can cause various short term and long term diseases. Organic matter content of wastewater can affect the aquatic life if discharged without treatment. Yang berarti pengolahan air limbah sangat penting dalam ilmu dan rekayasa lingkungan hidup. Air yang tercemar dapat mneyebakan penyakit dalam jangka panjang maupun jangka pendek. Bahan organik yang terkandumg dalam air limbah dapat mempengaruhi kehidupan jika limbah tersebut dibuang tanpa diolah terlebih dahulu.[4]

\subsection{Literature Review}

Banyak penelitian yang sebelumnya dilakukan mengenai Peningkatan Kinerja Administrasi Penjualan Chemical Water Treatment Product Dengan Pemanfaatan Sistem Informasi. Beberapa literature review sebagai berikut :

1. Penelitian yang dilakukan oleh Juergen Klinsman Wibowo dkk pada tahun 2013 yang berjudul "Perancangan dan Pembuatan Sistem Informasi Administrasi pada Toko Jaya Karya Berbasis Web". Pada penelitian ini membahas mengenai program aplikasi yang diimplementasikan dapat melakukan proses transaksi pembelian, retur pembelian, penjualan, retur penjualan, stock opname, pembayaran hutang dan piutang. Untuk desain sistem baru DFD digunakan aplikasi Power Designer 6, dan ERD digunakan aplikasi Power Designer 15.3. Aplikasi ini menggunakan bahasa pemrograman PHP dan databasenya menggunakan MySQL. Aplikasi ini mempunyai kemampuan melakukan penyimpanan data master dan transaksi, serta menyediakan informasi berupa laporan yang dibutuhkan termasuk perhitungan laba rugi dengan menggunakan metode FIFO yang mampu menghasilkan hasil yang akurat.[5]

2. Penelitian yang dilakukan oleh Yerika Mekarsena Nababan dkk pada tahun 2014 yang berjudul "Website Sebagai Sarana Administrasi dan Pemesanan Produk atau Jasa Pada Klinik Kecantikan XYZ”. Pada penelitian ini membahas mengenai sebuah website yang terintegrasi dengan basis data untuk mengelola data pelanggan klinik diharapkan dapat meningkatkan efisiensi dan efektifitas dalam proses administrasi di klinik. Jangkauan web yang luas juga memungkinkan untuk meningkatkan layanan klinik kepada pelanggannya, misalkan melalui pemesanan online dan juga konsultasi online. Untuk menjaga keamanan data, web ini membagi penggunanya menjadi 4 kelompok, yang masing-masing punya hak akses yang berbeda. Pembuatan web dilaksanakan melalui beberapa tahapan, mulai dari observasi dan wawanacara, perancangan basis data, aliran data, serta struktur menu, sampai dengan pengujian menu meggunakan white box testing dan black box testing.[6]

3. Penelitian yang dilakukan oleh Kalista Wiwaha Dewandaru dkk pada tahun 2015 yang berjudul "Rancang Bangun Sistem Monitoring Administrasi Penjualan Kendaraan Berbasis Web Dengan Administrative Workflow System. Pada penelitian ini membahas mengenai Sistem Monitoring Administrasi Penjualan Kendaraan Berbasis web yang digunakan untuk melakukan monitoring dan berkomunikasi terkait data administrasi penjualan kendaraan antara pelanggan, sales unit Astra Isuzu, sales leasing melalui internet, sehingga jika ada dokumen yang kurang lengkap dan mendekati batas tempo pengumpulan data administrasi penjualan atau terdapat data yang dirasa kurang valid maka sistem memberikan notifikasi kelengkapan data administrasi penjualan unit kendaraan Astra Isuzu melalui e-mail sehingga pihak - pihak tersebut dapat langsung melengkapi data yang dimaksud. Sistem Monitoring 
Administrasi Penjualan Kendaraan Berbasis web dapat diakses melalui Internet karena pengguna dapat menggunakan aplikasi melalui beberapa media mulai dari Smartphone, Personal Computer (PC) selama pengguna terkoneksi dengan Internet. Sistem ini diharapkan menjadi media untuk memantau kelengkapan dokumen administrasi penjualan unit kendaraan Astra Isuzu sesuai tenggat waktu yang ditentukan atau sebagai jalan komunikasi bertukar data kebutuhan administrasi penjualan unit kendaraan Astra Isuzu sehingga jika ada data administrasi yang kurang lengkap atau mengalami kesalahan maka sistem menyampaikan pesan melalui e-mail kepada pihak - pihak yang terlibat dalam proses penjualan kendaraan dan dapat melakukan pembaharuan dokumen yang dimaksud.[7]

4. Penelitian yang dilakukan oleh David Putra Harsalim dkk pada tahun 2012 yang berjudul "Rancang Bangun Sistem Informasi Administrasi Berbasis Web MenggunakanPhp Dan Mysql Pada Yukowina Jaya Motor Warehouse". Pada penelitian ini membahas mengenai aplikasi sistem informasi administrasi berbasis web sebagai penunjang kinerja internal agarlebih efisien. Bahasa pemrograman yang digunakan adalah PHP, dan MySQL. Aplikasi ini akan memudahkan user mengakses aplikasi tersebut dimanapun. Penggunaan PHP dapat berjalan dalam sistem operasi yang berbeda. Tujuan dari penelitian ini adalah menopang sistem kinerja internal dari proses distribusi masuk dan keluar barang secara keseluruhan yang dikemas dalam satu aplikasi sistem informasi administrasi untuk Yukowina Warehouse.[8]

5. Penelitian yang dilakukan oleh Wiiliam Surya Wijaya dkk pada tahun 2013 yang berjudul Rancang Bangun Aplikasi Sistem Informasi Administrasi pada Dealer Jaya Abadi Motor Jember". Pada penelitian ini membahas mengenai aplikasi sistem informasi yang mampu menyelesaikan proses administrasi yaitu proses pembelian, penjualan, stok barang, pengurusan surat kepemilikan sepeda motor serta pelaporan yang dapat membantu dalam hal administrasi pada perusahaan. Pada pembuatan program, digunakan bahasa pemrograman Visual Basic 6 dan SQL Server 2005 sebagai databasenya. Berdasarkan hasil pengujian yang diuji, terdapat fitur-fitur dalam aplikasi yang dibuat misalnya fitur pembelian, fitur penjualan, fitur stok barang, dan sebagainya telah berjalan sesuai yang diharapkan.[9]

\section{HASIL DAN PEMBAHASAN}

\subsection{Alternatif Pemecahan Masalah}

Setelah meneliti dan mengamati permasalahan yang ada pada sistem yang sedang berjalan, supaya memudahkan koordinasi tentang administrasi penjualan water treatment chemical product , maka alternatif pemecahan masalah yang diusulkan adalah:

1. Membuat rancangan program sistem informasi administrasi penjualan water treatment chemical product dimana setiap harinya mendapatkan informasi yang lengkap tentang masuknya data yang akan ditagihkan kepada pelanggan.

2. Menerapkan rancangan aplikasi sistem tersebut pada Perusahaan pengolahan air limbah sehingga dapat digunakan oleh bagian yang berkaitan.

\subsection{Use Case Diagram Sistem Yang Diusulkan}

Dibawah ini adalah Use Case Diagram yang diusulkan untuk menggambarkan proses sistem administrasi penjualan chemical water treatment product pada Perusahaan pengolahan air limbah: 


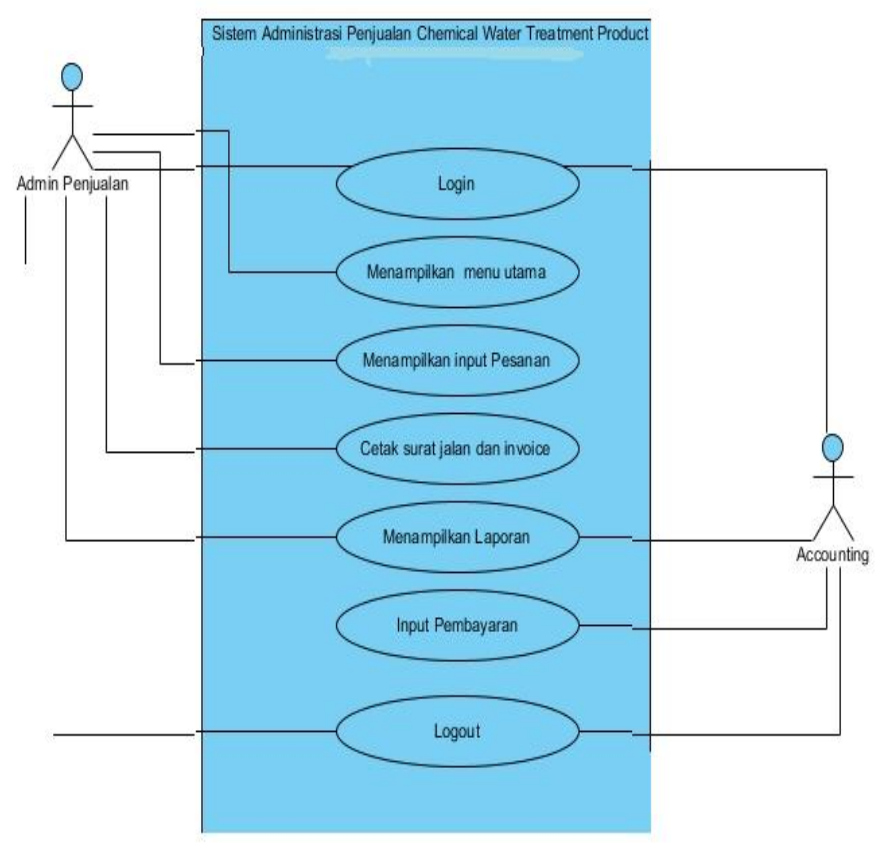

Gambar 1. Use Case Diagram Sistem

Berdasarkan gambar 1. Use Case Diagram usulan terdapat:

1. Satu sistem yang mencangkup kegiatan sistem administrasi penjualan chemical water treatment product

2. Actor yang melakukan kegiatan didalam sistem yaitu : Admin Penjualan dan Accounting

3. 7Use Case yang dapat dilakukan oleh Actor tersebut diantaranya : Login, Menampilkan menu utama, menampilkan input pesanan, cetak surat jalan dan invoice, menampilkan laporan,input pembayaran, logout

\subsection{Activity Diagram Yang Diusulkan}

Dibawah ini adalah Activity Diagram yang diusulkan untuk menggambarkan proses sistem administrasi penjualan chemical water treatment product pada Perusahaan pengolahan air limbah:

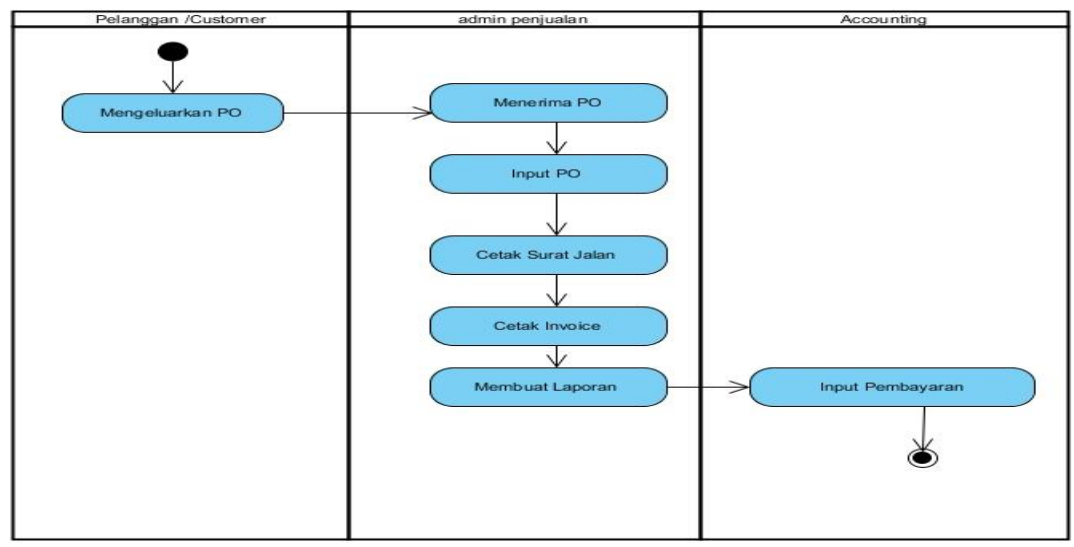

Gambar 2. Activity Diagram 
Berdasarkan gambar 4.2 Activity Diagram usulan terdapat:

1. 1 Initial Node, objek yang diawali

2. 8 Action, sistem yang mencerminkan eksekusi dari suatu aksi

3. 1 Activity Final Node, objek yang di akhiri

Sequence Diagram Yang Diusulkan

Dibawah ini adalah Sequence Diagram yang diusulkan untuk menggambarkan proses sistem administrasi penjualan chemical water treatment product pada Perusahaan pengolahan air limbah

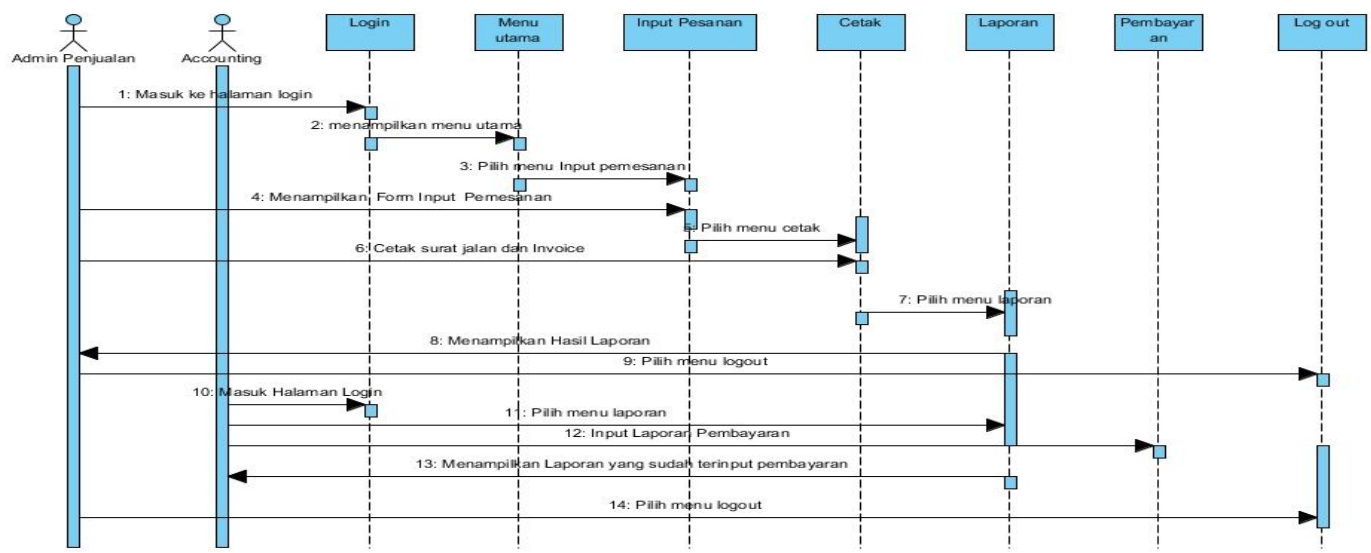

Gambar 3. Sequence Diagram

Berdasarkan gambar 3 Sequence Diagram diatas usulan ini terdapat:

1. Satu sistem yang mencangkup kegiatan sistem administrasi penjualan chemical water treatment product

2. Actor yang melakukan kegiatan didalam sistem yaitu : Admin Penjualan dan Accounting

3. 14 Message, spesifikasi dari komuniksi antar objek yang membuat informasi aktifitas yang terjadi.

\subsection{Implementasi}

Rancangan Program

1. Tampilan Login

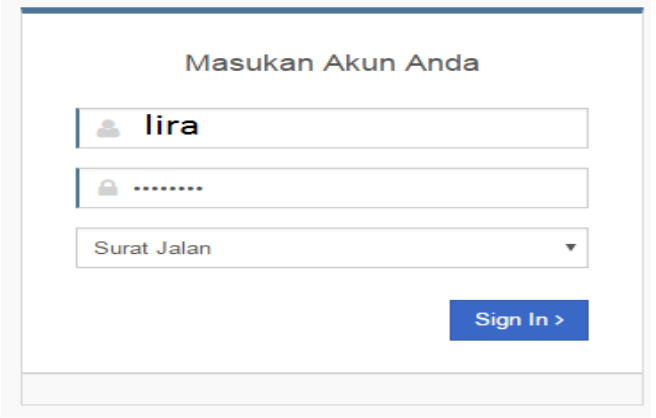

Gambar 4. Tampilan Login 
Tampilan diatas akan muncul jika user telah masuk ke web browser dan ingin melakukan login sistem. User harus menginput username beserta password dan memilih level akses jika ingin masuk ke sistem.

2. Tampilan Beranda Surat Jalan

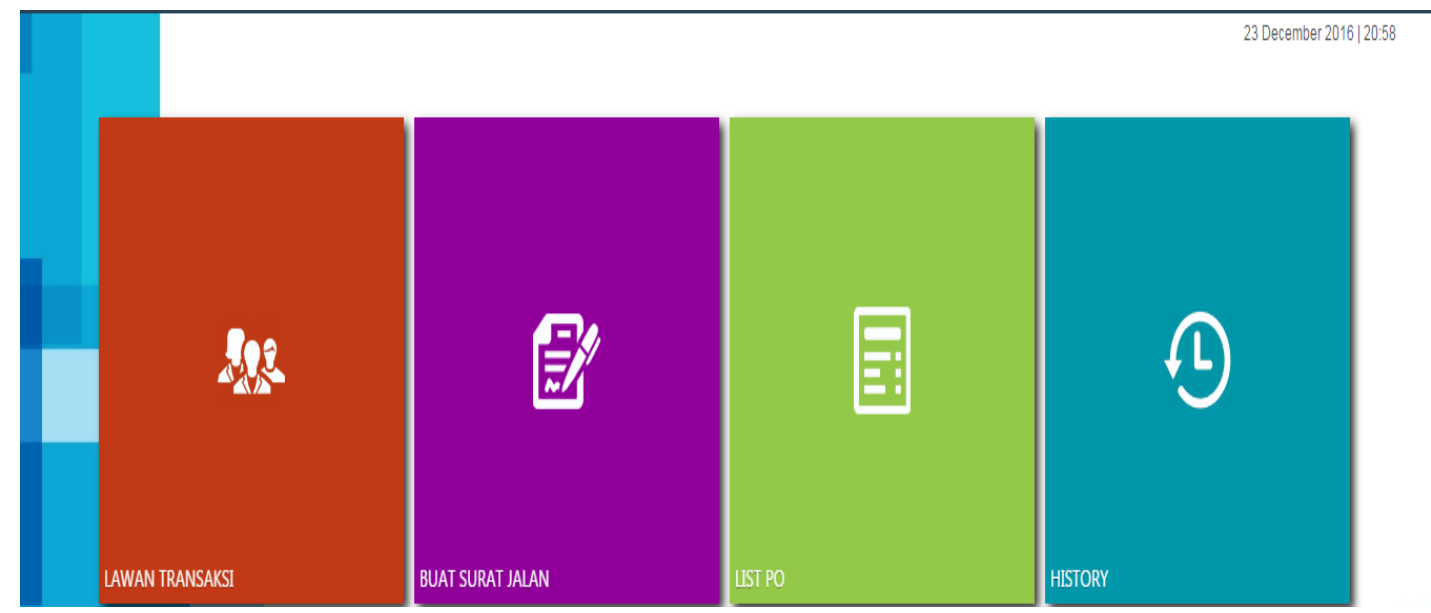

Gambar 5. Tampilan Menu Utama

Tampilan halaman utama akan muncul ketika user login ke level Surat Jalan. Terdapat menu buat surat jalan ,Lawan transaksi,list PO

3. Tampilan penginputan surat jalan / input pemesanan

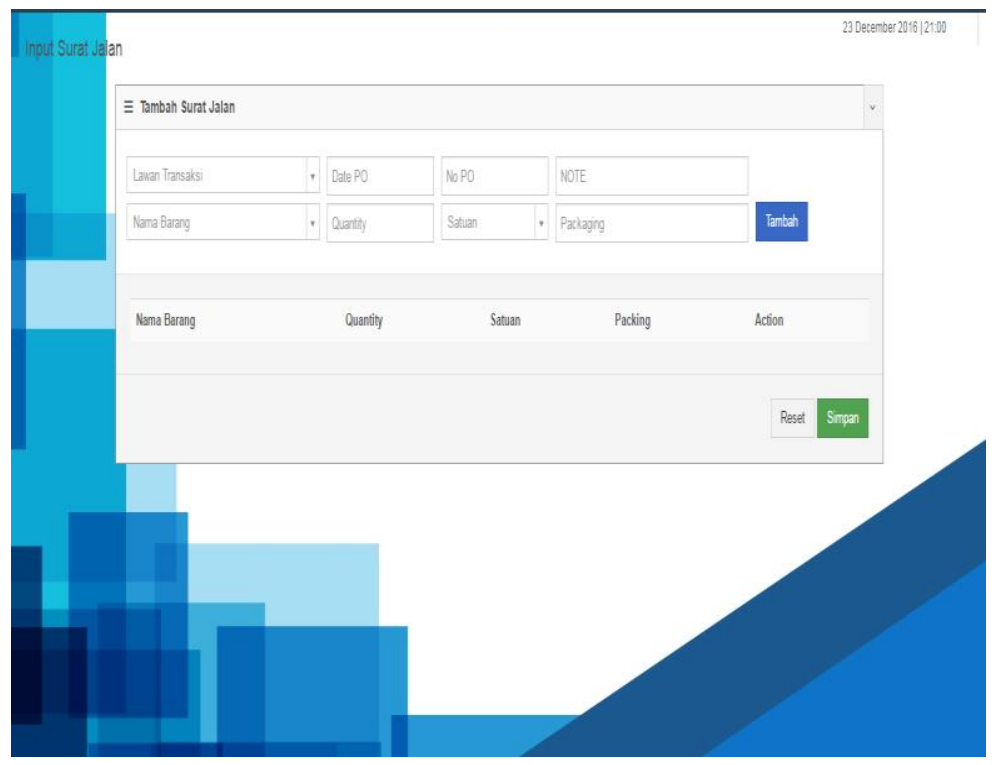

Gambar 6. Tampilan Menu Barang 
Tampilan diatas akan muncul jika user memilih menu Buat Surat Jalan. Menu tersebut dapat digunakan untuk menginput Nama Barang, Lawan Transaksi, Date Po, No Po, Quantity, Satuan, Packing dan Note. Setelah itu, data yang diinput akan otomatis masuk ke List PO.

4. Tampilan Referensi lawan transaksi

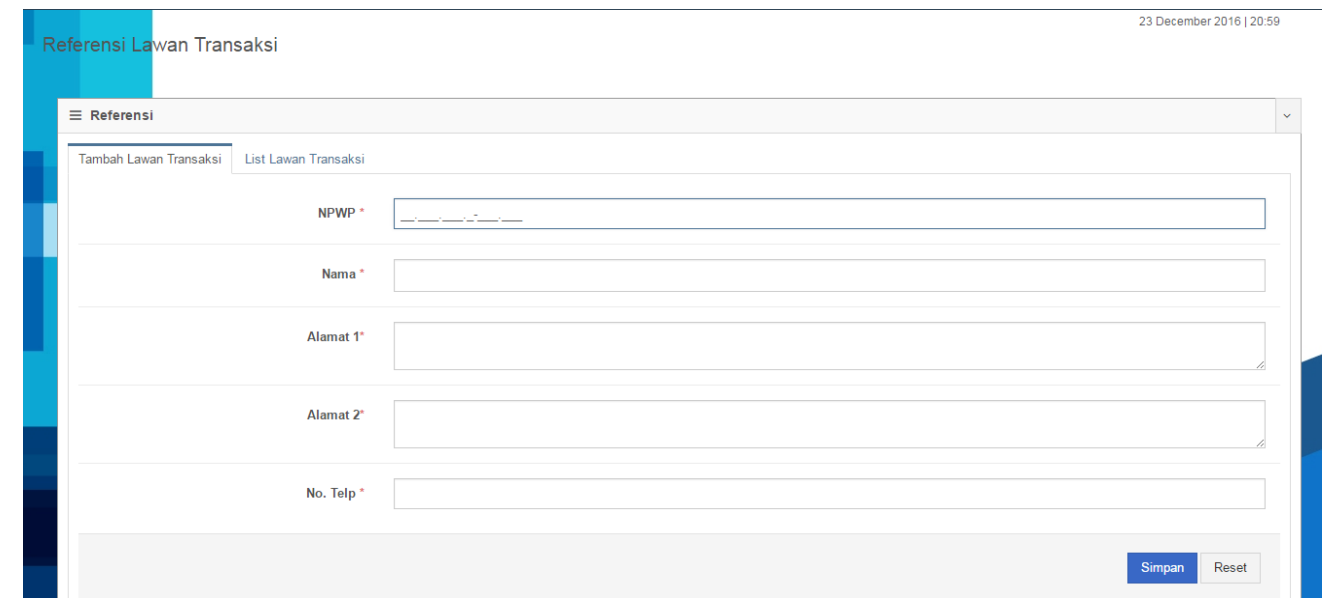

Gambar 7. Tampilan Lawan Transaksi

Tampilan diatas akan muncul jika user memilih menu referensi lawan transaksi. Menu tersebut dapat digunakan untuk penambahan lawan transaksi dan perubahan data lawan transaksi. Setelah itu, data yang diinput akan otomatis masuk ke menu List Lawan transaksi.

5. TampilanList PO

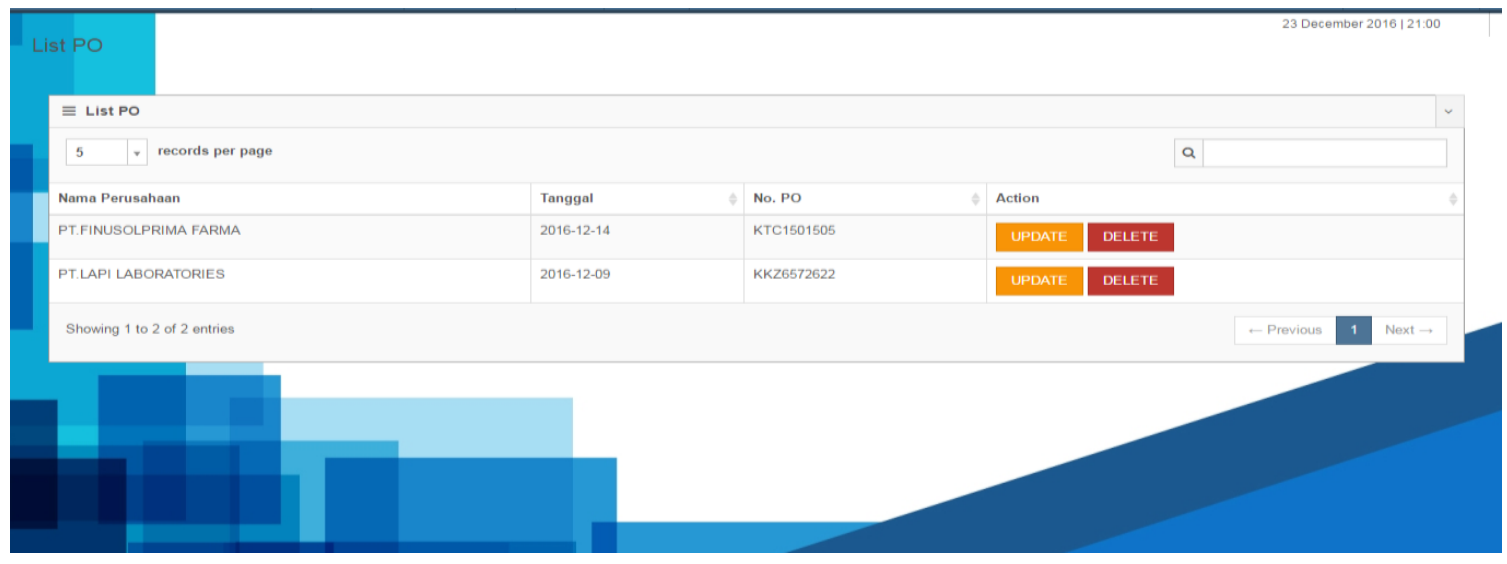

Gambar 8. Tampilan List PO

Tampilan diatas akan muncul jika user memilih fasilitas cari. User dapat mengetahui laporan data List PO yang belum dikirim pada menu tersebut. 
6. Tampilan Beranda Invoice

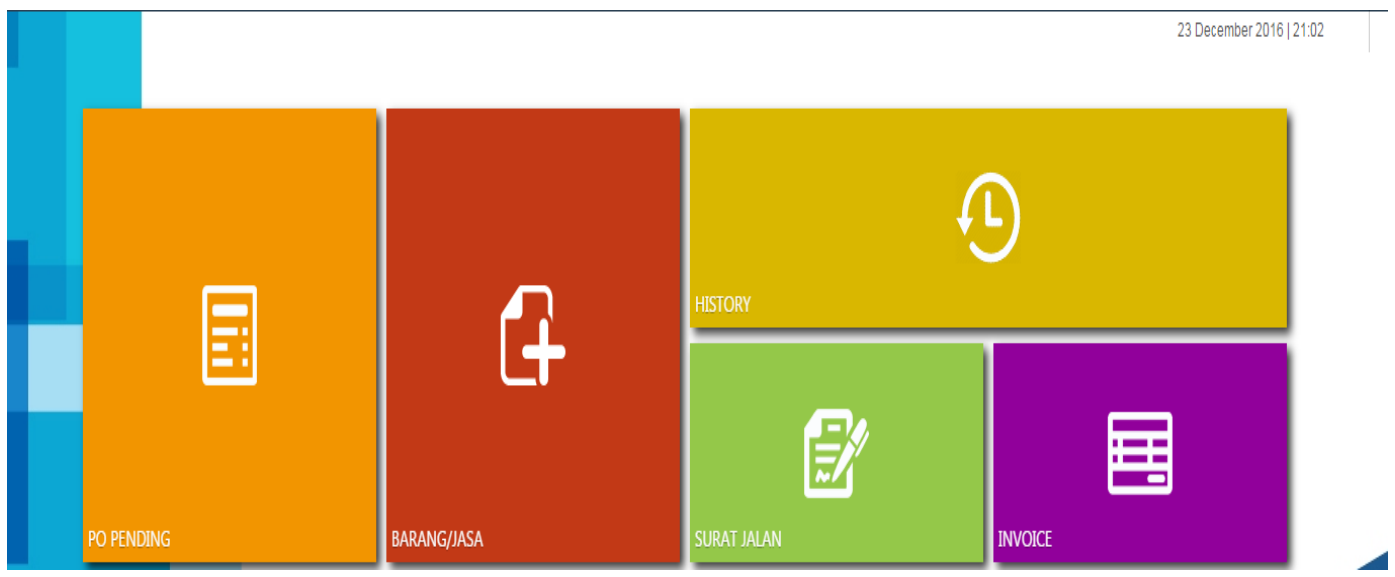

Gambar 9. Tampilan Menu Utama Invoice

Tampilan halaman utama akan muncul ketika user login. Terdapat menu buat invoice,PO pending,Referensi barang dan jasa.

7. Tampilan Referensi Barang dan Jasa

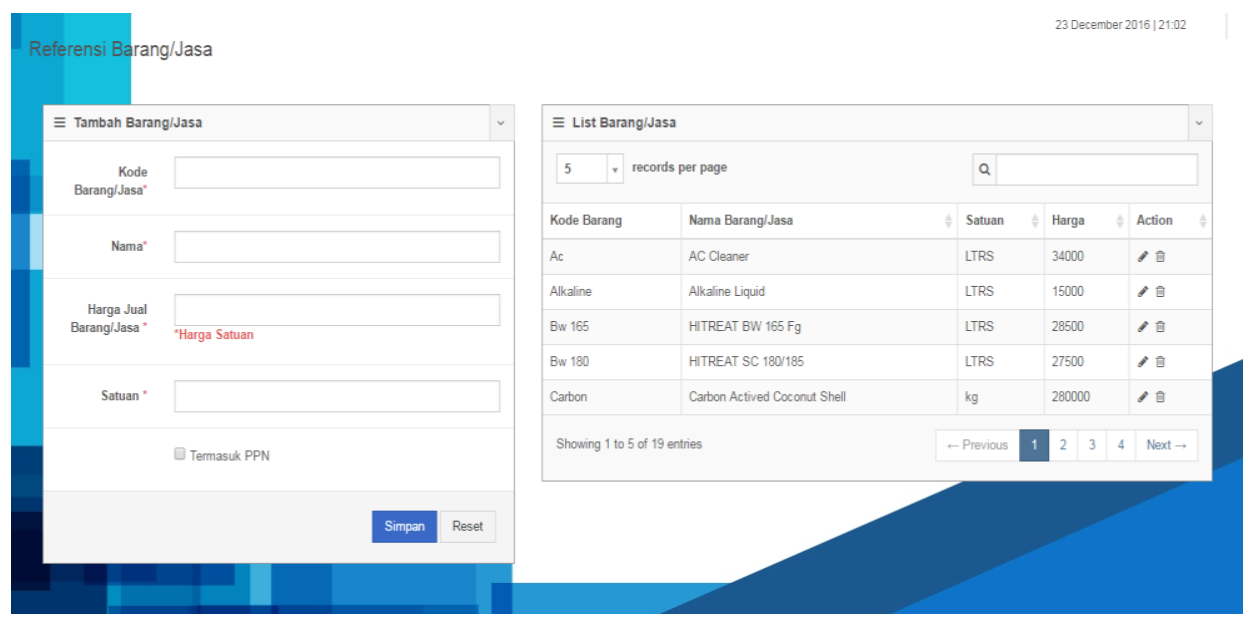

Gambar 10. Tampilan Referensi Nama Barang dan Jasa

Tampilan diatas akan muncul jika user memilih menu referensi barang dan jasa. Menu tersebut dapat digunakan untuk penambahan barang, perubahan harga barang dan perubahan deskripsi barang. Setelah itu, data yang diinput akan otomatis masuk ke menu list barang dan jasa. 
8. Tampilan Buat Invoice

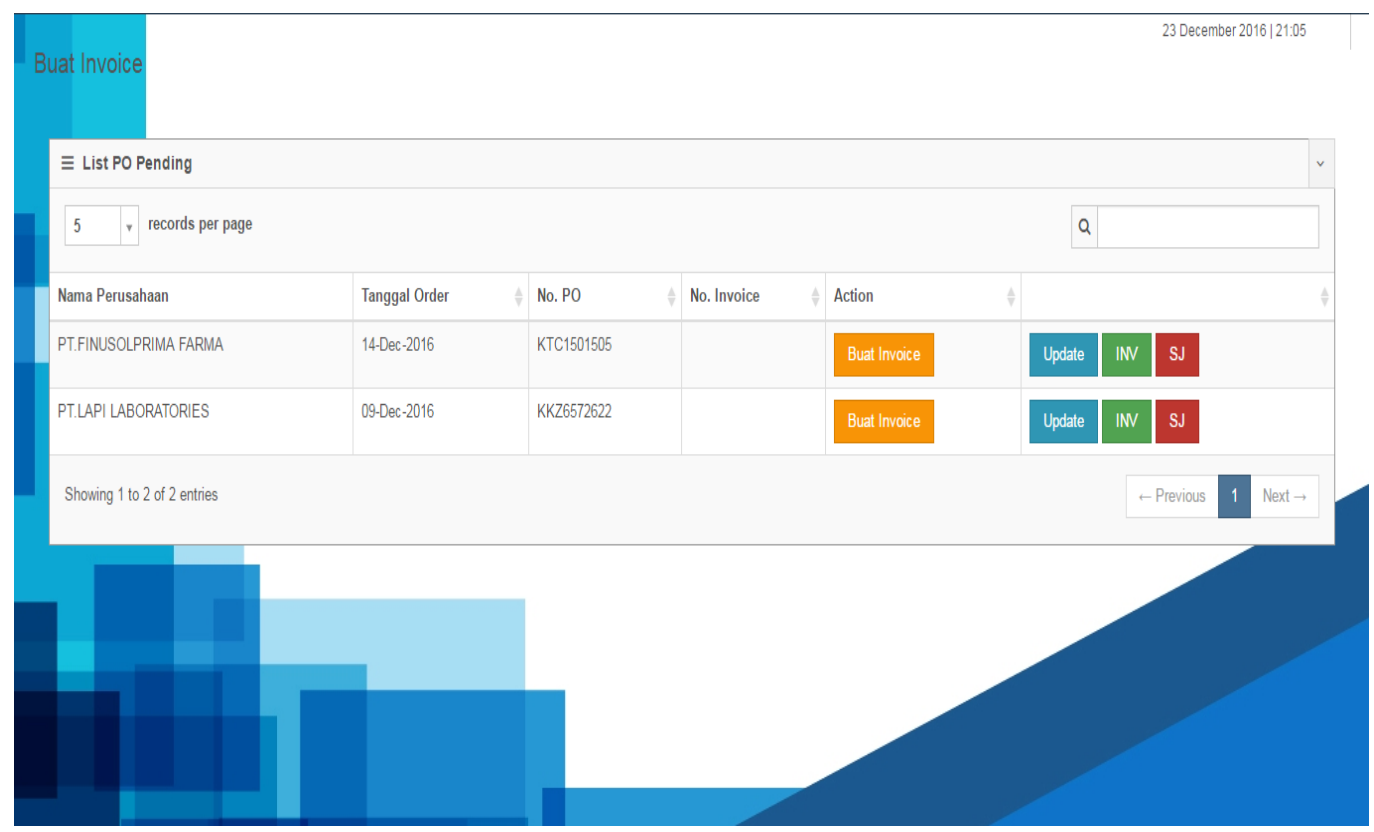

Gambar 11. Tampilan Buat Invoice

Tampilan diatas akan muncul jika user memilih menu Invoice klik buat Invoive. Menu tersebut berisikan tentang copy link dari surat jalan yang sudah di cetak dan dikirim.

9. Tampilan Beranda Accounting

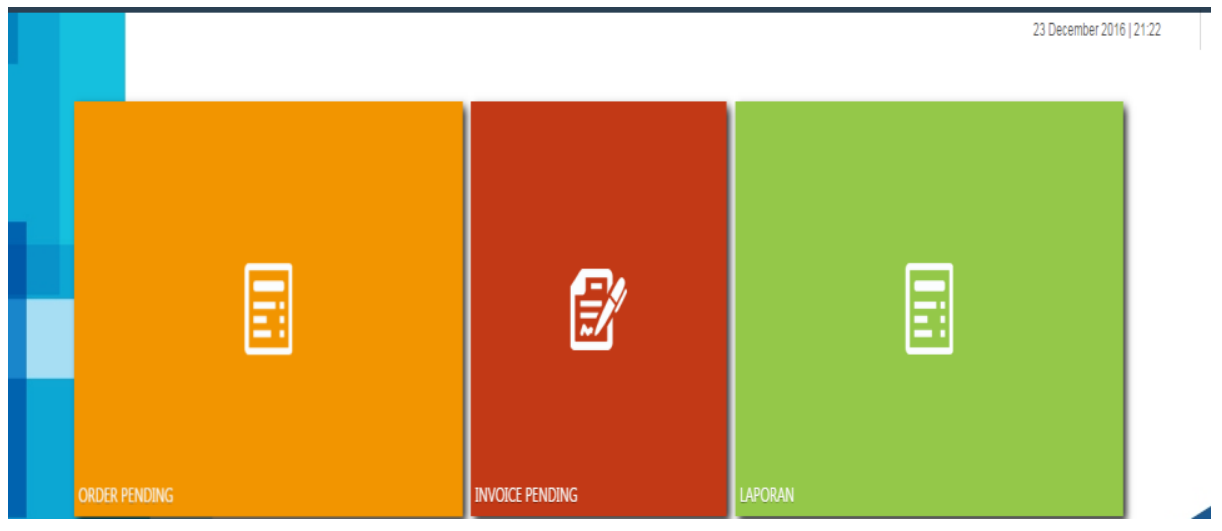

Gambar 12. Tampilan Menu Utama Invoice

Tampilan halaman utama akan muncul ketika user loginlevel Accounting. Terdapat menu Laporan penjualan. 
10. Tampilan Laporan Penjualan

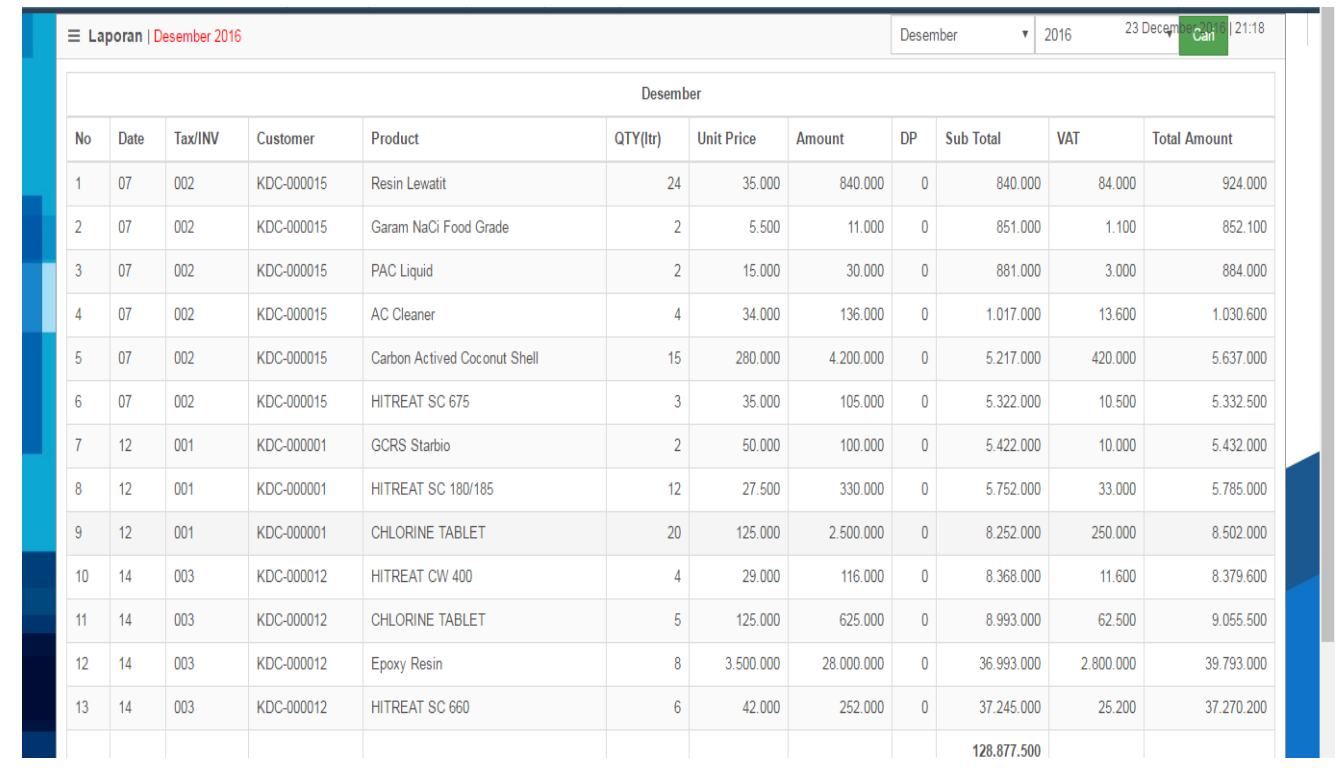

Gambar 13. Tampilan Menu Laporan Penjualan

Tampilan diatas akan muncul jika user memilih Laporan Penjualan. User dapat mengetahui laporan penjualan barang pada menu tersebut.

\section{DAFTAR PUSTAKA}

[1]. W. B. Anita. 2012. "Pengaruh Pemasaran Online Terhadap Keputusan Pembelian Produk". Jurnal CCIT Vol 5 No 2, Januari. Perguruan Tinggi Raharja.

[2]. Yuhefizar. 2011. "Menguasai Internet Teknologi dan Aplikasi”. Jakarta, PT Elex Media Komputindo.

[3]. Fahmi, Irham. 2015. "Pengantar Ilmu Administrasi Bisnis”. Bandung, Alfabeta.

[4]. Kulkarni, Sunil J. \& Pallavi M Kherde. 2015. "A Review on Advanced Membrane Separation Methods for Water Treatment." Galore Knowledge Publication Pvt. Ltd: Vol 2, No. 8.

[5]. Juergen K, Wibowo, Leo W, Santoso. 2013. "Perancangan dan Pembuatan Sistem Informasi Administrasi pada Toko Jaya Karya Berbasis Web”. Jurnal Infra Vol. 1 No. 2. Surabaya, Universitas Kristen Petra.

[6]. Yerika M, Nababan, Nina Sevani. 2014. "Website Sebagai Sarana Administrasi dan Pemesanan Produk atau Jasa Pada Klinik Kecantikan XYZ”. Jurnal Teknik dan Ilmu Komputer Vol. 03 No. 11. Jakarta, Universitas Kristen Krida Wacana.

[7]. Kalista W, Dewandaru, Antok Supriyanto, Tan Amelia. 2015. "Rancang Bangun Sistem Monitoring Administrasi Penjualan Kendaraan Berbasis Web Dengan Administrative Workflow System”. JSIKA Vol. 4, No. 2. Surabaya, STMIK Stikom.

[8]. David P, Harsalim, Rinabi Tanamal. 2012. "Rancang Bangun Sistem Informasi Administrasi Berbasis Web Menggunakan Php Dan Mysql Pada Yukowina Jaya Motor 
Warehouse". Jurnal Ilmiah Teknologi Informasi dan Multimedia (TIM) Vol. 2 No. 1. Surabaya, Universitas Ciputra.

[9]. Wiiliam S, Wijaya, Andreas Handojo, Silvia Rostianingsih. 2013. "Rancang Bangun Aplikasi Sistem Informasi Administrasi pada Dealer Jaya Abadi Motor Jember". Jurnal Infra Vol. 1 No. 2. Surabaya, Universitas Kristen Petra. 